\title{
G8 Ülkelerinde Ar-Ge Harcamalarının Ekonomik Büyüme Üzerindeki Etkisi: Bir Panel Veri Analizi ${ }^{a}$
}

\author{
Suzan Oğuz
}

\section{Özet}

Teknolojik yenilik ve gelişmeler, ekonomik olarak büyümek ve rekabet gücü kazanmak için önem teşkil etmektedir. Bu yenilik ve gelişmeler Araştırma ve Geliştirme (Ar-Ge) çalışmaları ile mümkün olmaktadır. Bu çalışmanın amacı, 1997-2017 dönemi yıllık verileri ile G8 ülkeleri (Almanya, Amerika Birleşik Devletleri, Birleşik Krallık, Fransa, İtalya, Japonya, Kanada, Rusya) için, Ar-Ge harcamalarının ekonomik büyüme üzerindeki etkisini, panel veri analizi yöntemi ile tespit etmektir. Çalışmanın sonucunda ampirik bulgular, G8 ülkeleri için Ar-Ge harcamaları ve ekonomik büyüme arasında pozitif ve anlamlı bir ilişki olduğunu göstermektedir.
Anahtar Kelimeler

Teknolojik Yenilik

Ar-Ge

Ekonomik Büyüme

Panel Veri Analizi

Makale Hakkında

Geliş Tarihi: 27.08.2020

Kabul Tarihi: 25.12.2020

Doi: 10.18026/cbayarsos.786505

\section{The Effect of R\&D Expenditures on Economic Growth in G8 Countries: A Panel Data Analysis}

\begin{abstract}
Technological innovations and developments are important in terms of growing economically and acquiring competitiveness. These innovations and developments are made possible through Research and Development (R\&D) studies. This study aims to determine the effect of R\&D expenditures on economic growth for G8 countries (Germany, United States of America, United Kingdom, France, Italy, Japan, Canada, Russia) through panel data analysis method through the annual data of period between 1997 and 2017. As a result of the study, empirical results show a positive and significant relationship between R\&D expenditure and economic growth for G8 countries.
\end{abstract}

Keywords

Technological Innovation

$\mathrm{R} \& \mathrm{D}$

Economic Growth

Panel Data Analysis

\begin{aligned} About Article \\ \hline Received: 27.08 .2020 \\ Accepted: 25.12 .2020\end{aligned}

Doi: 10.18026/cbayarsos.786505

\footnotetext{
a. Bu çalışma, 4-6 Eylül 2019 tarihlerinde düzenlenen II. Business and Organization Conference'de sözlü sunum olarak sunulmuştur.

b İletişim Yazarı: suzanoguz@cag.edu.tr

c Arş. Gör., Çağ Üniversitesi, İktisadi ve İdari Bilimler Fakültesi, Uluslararası Ticaret ve Lojistik Bölümü, Orcid: 0000-0003-4876-3173
} 


\section{Giriş}

Ekonomik büyümenin ve uluslararası alanda rekabet gücü kazanmanın en önemli koşullarından bir tanesi, teknolojik alanda yapılan yeniliklerdir. Teknolojik yenilikler ise araştırma geliştirme (Ar-Ge) sonucu ortaya çıkmaktadır. Ar-Ge konusunun temelini, Ar-Ge için yapılan tüm faaliyetler ve bu faaliyetler için yapılan harcamalar oluşturmaktadır.

Ekonomik büyüme, üretim kapasitesinin artırılması yoluyla daha fazla ürün ve hizmet üretilmesi sonucu gerçekleşmektedir. Zaman içerisinde ülkelerin üretim faktöründeki artışlar ve teknolojik düzeyinde yaşanan gelişmeler ile üretim kapasitesi artmakta ve daha fazla miktarda ürün ve hizmet üretebilme imkanı doğmaktadır (Ertek, 2009: 289). Ülkeler, eğitime daha fazla kaynak ayırarak, diğer ülkelerle işbirliği yaparak, teknoloji transferi için doğrudan yabancı yatırımları destekleyerek ve kamu ve özel sektörün Ar-Ge'ye yatırım yapmalarını özendirerek birbirleri arasındaki ekonomik büyüme farklarını en aza indirmeye çalışmaktadır (Göçer, 2013: 216).

Yenilik yapmak, rekabetin yoğun olduğu ekonomik yapının en önemli unsurlarından bir tanesi olarak kabul edilmektedir. Yeniliklerin büyük bir kısmı ise bilgi ve teknoloji üreten Ar-Ge faaliyetleri sonucu ortaya çıkmaktadır (Seyidoğlu, 2009, 669). Büyüme ve gelişme ekonomisinde teknoloji teriminin özel bir anlamı bulunmaktadır. Teknolojii üretim sürecinde girdilerin çıktıya dönüşme yöntemi olarak ifade edilmektedir. Yeni ve yaratıcı fikirler, üretim teknolojisini geliştirerek daha fazla ve/veya daha iyi üretim çıktısına olanak sağlamaktadır (Jones, 2001: 73). Ar-Ge ile teknolojiye yapılan yatırımlar sonucunda ortaya çıkan yenilikler, sürdürülebilir bir ekonomik büyümeyi sağlamak için öncü durumdadır. Araştırma faaliyetlerine yönelik yapılan yatırımların artması, yeni ürünlerin yaratılması ve yatırımcıların borsaya kolay erişimi özel sektörün ve kamu sektörünün gelişmesini sağlayarak ve ülke nüfusunun yaşam koşullarını iyileştirecektir (Pece vd., 2015: 461).

Bilginin ve yeni fikirlerin rekabet üstünlüğü kaynağı olarak ortaya çıkışı, ekonomi politikasında bir değişime neden olmuştur (Audretsch, 2018: 648). Bilgi ekonomisi hız ve yenilik ekonomisi olarak adlandırılmaktadır. Bu yüzden bilgi çağında Ar-Ge çalışmaları bir ihtiyaç olmaktan çıkmış zorunluluk haline gelmiştir. Ar-Ge çalışmaları yapan işletmeler teknolojik alanda yenilikler yapabilmekte ve ilgili sektör gelişme sağlayarak ülke ekonomisinin daha iyi bir performans düzeyine ulaşması yolunda fayda sağlayabilmektedir. Günümüzde ülke ekonomilerinin performans düzeyleri, Ar-Ge faaliyetlerine yönelik istihdam, bilimsel yayın sayısı, ileri teknoloji ürün ihracatı, ticari marka sayısı ve patent gibi Ar-Ge göstergeleri ile ölçülmektedir (Ünal ve Seçilmiş, 2013: 24).

Ar-Ge faaliyetlerine yönelik yapılan harcamalar, yenilik yaratarak ekonomik büyümeye katkı sağlamaktadır. Son yıllarda yapılan çalışmalar incelendiğinde araştırmacılar, endüstriyel alanda yapılan yeniliklerin, ekonomik gelişme ve bölgesel kalkınma üzerindeki olumlu etkilerini vurgulamıştır (Shefer ve Frenkel, 2005: 25). Literatürde, Ar-Ge harcamalar ve ekonomik büyüme arasındaki ilişkiyi araştıran bir çok çalışma (Lichtenberg, 1993; Goel ve Ram, 1994; Del Monte ve Papagni, 2003; Ülkü, 2004; Altın ve Kaya, 2009; Samimi ve Alerasoul, 2009; Gülmez ve Yardımcıoğlu; 2012; Göçer, 2013; Yıldırım ve Kantarcı, 2014; Altıntaş ve Mercan, 2015; Blanco vd,., 2016; Freimane ve Balina, 2016; Pradhan vd., 2016; Özkan ve Yılmaz, 2017) mevcuttur. Yapılan ampirik çalışmalarda genel olarak, Ar-Ge harcamalarının ekonomik büyüme üzerinde pozitif ve anlamlı bir etkisi olduğu sonucuna varılmıştır. Ancak Lichtenberg (1993) 74 ülke için yaptığı çalışmada, özel sektör ve kamu 
sektöründe yapılan Ar-Ge harcamalarının ekonomik büyüme üzerindeki etkisini incelemiştir. Çalışmanın bulguları, özel sektör tarafından yapılan Ar-Ge harcamaları ile ekonomik büyüme arasında bir ilişki olduğunu gösterirken; kamu sektörü tarafından yapılan Ar-Ge harcamalarının ekonomik büyümeyi etkilemediğini, hatta bazı yıllarda negatif bir etki yarattığını göstermektedir. Goel ve Ram (1994) çalışmalarında, 34 az gelişmiş ve 18 gelişmekte olan ülke için yaptıkları çalışmada, sadece yüksek gelirli ülkelerde Ar-Ge harcamaları ve ekonomik büyüme arasında bir ilişki olduğunu diğer ülkelerde böyle bir ilişki olmadığını tespit etmişlerdir. Samimi ve Alerasoul (2009) ise 30 gelişmekte olan ülkeyi ele aldıkları çalışmalarında, Ar-Ge harcamaları ve ekonomik büyüme arasında anlamlı bir ilişki olmadığı sonucuna varmışlardır. Yazarlar bu durumun nedeni olarak; gelişmekte olan ülkelerde Ar-Ge harcamaları düşük olduğunu, bu yüzden ekonomik büyüme üzerinde anlamlı bir etki yaratmadığını vurgulamıştır.

Bu çalışmanın amacı, G8 ülkelerinde (Almanya, Amerika Birleşik Devletleri, Birleşik Krallık, Fransa, İtalya, Japonya, Kanada, Rusya) için, Ar-Ge harcamalarının ekonomik büyüme üzerindeki etkisini, 1997-2017 yıllarına ait verileri kullanarak panel veri analizi yöntemi ile tespit etmektir. Veriler Dünya Bankası ve OECD veri tabanlarından alınarak Stata 14 paket programı aracılığıyla analiz edilmiştir. Çalışma kapsamında ele alınan ülkeler sanayisi en gelişmiş ülkeler olduğundan çalışmanın, Ar-Ge yatırımlarının bu ülkelerin ekonomik büyümeleri üzerindeki etkisinin tespiti ve bu doğrultuda diğer ülkeler için çözüm önerileri içermesi bakımından literatüre bir katkı sağlayacağı düşünülmektedir.

\section{G8 Ülkelerinde Ar-Ge ve Ekonomik Büyüme}

Dünyanın en büyük endüstrileşmiş ülkelerinin bir forum olması fikri, 1973 petrol krizi sonrası yaşanan küresel durgunluktan dolayı ortaya çıkmıştır (Öztürk, 2016: 121). 1975 yılında, G6 (Almanya, Amerika Birleşik Devletleri, Birleşik Krallık, Fransa, İtalya, Japonya) olarak başlatılan 1976' da Kanada'nın katılımıyla G7'ye dönüşen ve son olarak 1998' de Rusya Federasyonunun katılımı ile genişleyen G8 kavramı, bu sekiz ülkeyi temsil etmekte olup "Sekizler Grubu-Group of Eight" anlamina gelmektedir (Hajnal, 2016: 1). G8 ülkeleri, toplam dünya nüfusunun yaklaşık \%13'ünü ve küresel gayri safi hâsılanın\%48'sini oluşturmaktadır (Dünya Bankası, 2019). Bu ülkeler dünyanın öncü nükleer enerji üreticisi ülkeleri olmakla birlikte Birleşmiş Milletlerin beş daimi üyesinden dört tanesi bu grup içerisinde yer almaktadır. Ayrıca G8 ülkeleri, IMF'de en fazla oy hakkına sahip olan ülkelerdir (Altay vd., 2011, 4). G8 zirvelerinde, uluslararası ticaret, hükümetler arası iş birliğini güçlendirmek, uluslararası kuruluşların faaliyetlerini daha canlı hale getirmek, gelecekte ortaya çıkabilecek sorunlar için ortak çözüm önerileri geliştirmek ve gelişmekte olan ülkelere yönelik iş birliği girişimleri gibi konular üzerinde görüşmeler yapılmaktadır (Öztürk, 2016: 112).

Yenilik yapmanın zorlu bir süreç olduğunu benimseyen ülkeler ekonomik büyüme ve kalkınma süreçlerinde öncelikle Ar-Ge temelli politikalar uygulamaktadır. Özellikle gelişmiş ülkelerin yaptığ1 yenilikler uzun dönemde bu ülkelerin ekonomik olarak büyümesine fayda sağlamakyadır (Saatçioğlu ve Bildirici, 2017: 44). Ayrıca, gelişmiş ve gelişmekte olan ülkelerde teknolojik üretim sonucu oluşan katma değerin ekonomik büyüme üzerinde önemli bir etkisi vardır ( Sağlam vd., 2017: 162). Ar-Ge için yapılan faaliyetlerin ekonomik büyüme ve ülkelerarası rekabet üzerindeki etkisinin giderek artmasılla, ülkeler bu faaliyetlere daha çok önem vermektedir. Gelişmiş ülkelerde, Ar-Ge faaliyetlerine yönelik yapılan harcamalar belirli bir seviyeye gelmekle birlikte artmaya devam etmektedir. Tablo 1'de G8 ülkelerinde yapılan Ar-Ge harcamalarının GSYİH içindeki payı gösterilmektedir. 
Tablo 1. G8 Ülkelerinde Ar-Ge harcamalarının GSYİH İçindeki Payı (\%)

\begin{tabular}{cccccc}
\hline Ülkeler & $\mathbf{1 9 9 7}$ & $\mathbf{2 0 0 2}$ & $\mathbf{2 0 0 7}$ & $\mathbf{2 0 1 2}$ & $\mathbf{2 0 1 7}$ \\
\hline ABD & 2.48 & 2.55 & 2.63 & 2.68 & 2.78 \\
Almanya & 2.18 & 2.42 & 2.44 & 2.86 & 3.03 \\
Birleşik Krallık & 1.54 & 1.62 & 1.62 & 1.59 & 1.66 \\
Fransa & 2.14 & 2.17 & 2.02 & 2.22 & 2.18 \\
İtalya & 0.99 & 1.08 & 1.13 & 1.27 & 1.35 \\
Japonya & 2.77 & 3.01 & 3.34 & 3.20 & 3.21 \\
Kanada & 1.61 & 1.97 & 1.90 & 1.77 & 1.58 \\
Rusya & 0.97 & 1.15 & 1.03 & 1.02 & 1.10 \\
\hline
\end{tabular}

Kaynak: OECD, 2019

Yıllar itibari ile G8 ülkelerinde Ar-Ge harcamalarının GSYİH içindeki payının genel olarak arttığ1 görülmektedir. 2017 yılı verileri incelendiğinde ise, en yüksek payın \%3.21 ile Japonya'ya ait olduğu görülmektedir. Almanya \%3.03 ile ikinci sırada yer alırken ABD \%2.78 ile üçüncü sırada yer almaktadır. Rusya ise Ar-Ge harcamalarına GSYİH'dan ayırdığ $1 \% 1.10$ pay ile G8 ülkeleri içerisinde en son sırada yer almaktadır.

Toplumsal refahın daha iyi bir seviyeye gelmesinin en önemli göstergelerinden bir tanesi kişi başına düşen GSYİH'da meydana gelen artışlardır. Başka bir deyişle bu durum, GSYİH'nın nüfustan daha hızlı artması durumudur. Bu durumun gerçekleşmesi için de verimlilikte bir artış olması gerekmektedir. Kişi başına üretim ve gelirin artması, fiziksel sermaye ve teknoloji düzeyinin artması yoluyla gerçekleşmektedir (Ertek, 2009: 542). G8 ülkelerinde kişi başı GSYİH rakamları tablo 2'de gösterildiği gibidir.

Tablo 2. G8 Ülkelerinde Kişi Başı GSYİH (ABD Doları)

\begin{tabular}{cccccc}
\hline Ülkeler & $\mathbf{1 9 9 7}$ & $\mathbf{2 0 0 2}$ & $\mathbf{2 0 0 7}$ & $\mathbf{2 0 1 2}$ & $\mathbf{2 0 1 7}$ \\
\hline ABD & $31.459,13$ & $38.023,16$ & $47.975,96$ & $51.603,49$ & $59.927,92$ \\
Almanya & $27.045,71$ & $25.205,16$ & $41.814,81$ & $44.065,24$ & $44.681,08$ \\
Birleşik Krallık & $26.641,01$ & $29.863,58$ & $50.293,44$ & $42.018,72$ & $39.932,06$ \\
Fransa & $24.228,94$ & $24.177,33$ & $41.508,43$ & $40.874,70$ & $38.679,12$ \\
İtalya & $21.779,62$ & $22.196,50$ & $37.698,78$ & $34.814,12$ & $32.155,20$ \\
Japonya & $35.021,71$ & $32.289,35$ & $35.275,22$ & $48.603,47$ & $38.331,97$ \\
Kanada & $21.829,23$ & $24.169,28$ & $44.543,04$ & $52.542,34$ & $45.069,92$ \\
Rusya & $2.737,57$ & $2.377,53$ & $9.101,25$ & $15.434,57$ & $10.750,58$ \\
\hline
\end{tabular}

Kaynak: Dünya Bankası, 2019 
Tablo 2'de yer alan G8 ülkelerinin 1997-2017 yılları arasındaki verileri incelendiğinde, yıllar itibariyle en yüksek kişi başı GSYIHH'nın ABD'de, en düşük kişi başı GSYİH'nın ise Rusya'da olduğu görülmektedir. G8 ülkelerinde kişi başına düşen GSYİH'nın yüksek olması, gelişmiş sanayi faaliyetlerinden kaynaklanmaktadır. Dolayısıyla gelişmekte olan ülkelerin de ekonomik gelişme sağlayabilmesi için Ar-Ge faaliyetlerine daha fazla pay ayırmaları gerekmektedir.

\section{Metodoloji}

Bu çalışmada, Ar-Ge harcamalarının ekonomik büyüme üzerindeki etksini ölçmek üzere araştırmanın veri setine dahil olan G8 ülkelerinin 1997-2017 dönemlerini kapsayan verileri ele alınarak bir panel veri seti oluşturulmuştur. Bu amaç doğrultusunda, veri setinde yer alan değişkenler ve çalışmada kullanılan ekonometrik yöntemler açıklanmış ve analiz yapılarak bulgular tablolaştırılmıştır.

\section{Çalışmanın Veri Seti ve Tanımlayıcı Ístatistikler}

Ar-Ge harcamalarının ekonomik büyüme üzerindeki etkisi aşağıda gösterilen panel veri formatında regresyon modeli ile incelenmiştir.

Model: $\ln P C G D P_{i t}=\beta_{0}+\beta_{1} R_{i t}+\beta_{2} \ln E X C_{i t}+\mathcal{E}_{\text {it }}$

Burada;

$\beta_{0} \quad$ Sabit değeri,

$\beta_{1}, \beta_{2}, \beta_{3}$ :Tahmin edilecek katsayıları

$\mathcal{E}_{\text {it }}:$ Hata terimini,

i : Ülke grubunu,

t : :Zamanı ifade etmektedir.

Modelde; lnPCGDP; kişi başına düşen gayri safi yurtiçi hasılayı (US\$), RD; Ar-Ge faaliyetlerine yönelik yapılan harcamaları, lnExc ise reel efektif döviz kurunu temsil etmekte olup ekonomik büyümeye etkisi olduğu düşünülen kontrol değişken olarak modele dahil edilmiştir.

Tablo 3. Çalışmanın Veri Seti

\begin{tabular}{llll}
\hline & Değişken Adı & Kodu & Kullanım Şekli \\
\hline Bağımlı Değişken & Kişi Başına GSYİH & lnPCGDP & $\begin{array}{l}\text { Kişi başına düşen gayri safi yurtiçi } \\
\text { hasılanın doğal logaritması }\end{array}$ \\
Bağımsız Değişken & Ar-Ge Harcamaları & RD & Ar-Ge Harcamaları/GSYİH \\
Kontrol Değişken & Reel Efektif Döviz Kuru & lnEXC & Döviz kurunun doğal logaritması \\
& & &
\end{tabular}

Çalışmada bağımlı değişken olarak kullanılan ve ekonomik büyümenin temel göstergelerinden bir tanesi olan kişi başı GSYİH, GSYİH'nın ülke nufüsuna bölünmesiyle elde edilmektedir. Ekonomik büyümeye etkisi ölçülmek üzere modele bağımsız değişken olarak eklenen Ar-Ge harcamaları, her ülkenin yaptığı Ar-Ge harcamasının GSYİH içindeki 
payı alınarak elde edilmiştir. Modele kontrol değişken olarak eklenen döviz kuru için ise 2010 yılının baz alındığı reel efektif döviz kuru verilerinden yararlanılmış ve verilerin doğal logaritması alınarak analize dahil edilmiştir.

Tablo 4. Tanımlayıcı İstatistikler ve Korelasyon Matrisi

\begin{tabular}{cccc}
\hline Değişkenler & lnPCGDP & RD & lnEXC \\
\hline Gözlem Sayısı & 168 & 159 & 168 \\
Ortalama & 10.44817 & 2.022739 & 4.574817 \\
Standart Sapma & .5282325 & .6976948 & .1566697 \\
Minimum & 8.613526 & .95369 & 3.845278 \\
Maksimum & 10.88047 & 3.3994 & 4.83436
\end{tabular}

\section{Korelasyon Matrisi}

$\ln P C G D P \quad 1.000$

$\begin{array}{cccc}\text { RD } & 0.5879 & 1.000 & \\ \operatorname{lnExc} & 0.5063 & 0.1860 & 1.000\end{array}$

Tablo 4'te veri setindeki 8 ülke için 1997-2017 yılları arasındaki toplam gözlem sayısı, aritmetik ortalama, standart sapma, minimum ve maksimum değerler gibi özet bilgiler yer almaktadır. Korelasyon matrisi, değişkenler arasında var olan ilişkileri göstermektedir. Korelasyon matrisi incelendiğinde, bağımlı değişken olan kişi başı GSYİH ile bağımsız değişkenler arasında pozitif bir korelasyon olduğu görülmektedir. Korelasyon katsayıları incelendiğinde ise, kişi başı GSYİH'nın sırasıyla Ar-Ge harcamaları ve reel efektif döviz kuru ile; 0.58 ve 0.50 değerleri ile pozitif korelasyona sahip olduğu görülmektedir.

Tanımlayıcı istatistikler ve korelasyon matrisi sonrası, bağımsız değişkenler arasında çoklu doğrusal bağlantı sorununun varlığını sınamak üzere VIF (Varyans Enflasyon Faktörü) testi yapılmıştır.

Tablo 5. VIF Testi Sonuçları

\begin{tabular}{llc}
\hline Değişken & VIF Değeri & 1/VIF Değeri \\
\hline RD & 1.04 & 0.965413 \\
LnEXC & 1.04 & 0.965413 \\
Ortalama VIF İstatistik Değeri & 1.04 &
\end{tabular}

Tablo 5'teki VIF test sonuçları incelendiğinde, bağımsız değişkenler arasındaki VIF istatistik değerlerinin kabul edilebilir sınırlar içerisinde olduğu görülmektedir. VIF değerinin 10'dan küçük olması bağımsız değişkenler arasında çoklu doğrusal bağlantı sorunun olmadığını göstermektedir (Fogarty, 2018: 221). 


\section{Ampirik Bulgular}

Panel regresyon analizlerinde en sık kullanılan üç yöntem, literatürde havuzlanmış en küçük kareler modeli olarak ta bilinen klasik model, sabit etkiler modeli ve tesadüfi (rassal) etkiler modelidir. Bu üç modelden hangisinin kullanılacağını tespit etmek için ise iki farklı test uygulanmaktadır. Bu testler; Breusch-Pagan (1980) ve Hausman (1978) testleridir. Test sonuçları tablo 6 ' da gösterildiği gibidir.

Tablo 6. Breusch-Pagan ve Hausman Testi Sonuçları

\begin{tabular}{ccc}
\hline Test Adı & Ki-Kare Test İstatistiği & Olasılık Değeri \\
\hline Breusch-Pagan & 1031.80 & 0.00000 \\
Hausman & 0.71 & 0.7024 \\
\hline
\end{tabular}

Breusch-Pagan testi sonuçlarına göre birim etkilerin varyansının sıfıra eşit olduğu sıfır hipotezi reddedilmektedir. Bu durum, klasik modelin çalışma için uygun olmayacağını göstermektedir. Bu sonucu takiben yapılan Hausman test istatistiklerine göre olasılık değeri $0.05^{\prime}$ ten büyük çıkmıştır. Bu durum ise, tesadüfi etkiler tahmincisinin tutarlı ve etkin olduğunu, bu çalışmada tesadüfi etkiler modelinin kullanılması gerektiğini göstermektedir.

Panel verilerde kullanılan modellerin temelinde değişen varyans (heteroskedasite), otokorelasyon ve literatürde yatay kesitsel bağımlılık olarak ta isimlendirilen birimler arası korelasyon problemlerinin olmadığı varsayılmaktadır. Ancak kurulan modelde bu problemlerden bir veya birkaçının mevcut olması, tahmin edilen parametrelerde etkinlik kaybına ve standart hataların yanlış tahmin edilmesine sebep olmaktadır. Bu nedenle, model tahmin edildikten sonra bu problemlerin mevcut olup olmadığ1 istatistiksel olarak test edilmelidir (Güriş, 2015: 71).

Tesadüfi etkiler modeli için yapılan tahminlerde, hata terimlerinden herhangi birinin varyansının panel birimlerinde değişmesinden dolayı değişen varyans sorunu ortaya çıkabilmektedir. Bu çalışma kapsamında kurulan modelde, değişen varyans probleminin varlığ1 Levene (1960)-Brown (1974) ve Forsythe (1974) testi ile tespit edilmiştir. Tablo 7'de değişen varyans test sonuçları gösterilmektedir.

Tablo 7. Levene, Brown ve Forsythe Değişen Varyans Test Sonuçları

$$
\begin{array}{lll}
W 0=3.6824925 & \mathrm{df}(7,151) & \operatorname{Pr}>\mathrm{F}=0.00102245 \\
W 50=2.6601230 & \mathrm{df}(7,151) & \operatorname{Pr}>\mathrm{F}=0.01249461 \\
W 10=3.3943016 & \mathrm{df}(7,151) & \operatorname{Pr}>\mathrm{F}=0.00208723
\end{array}
$$

Tablo 7' de sekiz birim için kalıntıların ortalamaları ve standart sapmalar gösterilmiştir. Sekiz birim için kalıntıların ortalamalarının ve standart sapmalarının hesaplandığ istatistiği birim sayısı ve her birimin frekanslarının bir eksiğinin toplamı serbestlik dereceli F dağılımı ile değerlendirilmektedir. Levene, Brown ve Forsythe'in test istatistikleri incelendiğinde, serbestlik derecesinin $(7,151)$, olasılık düzeylerinin ise düşük değerler olduğu görülmektedir. Bu durumda birimlerin varyanslarının eşit olduğu sıfır hipotezi reddedilmektedir, yani tesadüfi etkiler modeli için değişen varyans problemi mevcuttur. 
Tesadüfi etkiler modelinde, otokorelasyon probleminin varlığı, elde edilen standart hataların sapmalı olmasına ve parametrelerin katsayı sonuçlarının etkin olmamasına yol açabilmektedir. Çalışma için kurulan tesadüfi etkiler modelinde otokorelasyonun probleminin olup olmadığını tespit etmek için Durbin-Watson ve Baltagi-Wu'nun yerel en iyi değişmez testi uygulanmıştır. Otokorelasyon test sonuçları tablo 8'degösterildiği gibidir.

Tablo 8. Durbin-Watson, Baltagi-Wu LBI Otokorelasyon Testi Sonuçları

$$
\begin{aligned}
\text { Durbin-Watson } & =.30633038 \\
\text { Baltagi-Wu LBI } & =.6199627
\end{aligned}
$$

Otokorelasyon test istatistiği değerinin 2'den küçük olması modelde otokorelasyon olduğu anlamina gelmektedir. Tablo 8 incelendiğinde, kritik değerlerin 2'den oldukça küçük olduğu görülmektedir. Bu durum, kurulan modelde otokorelasyon probleminin mevcut olduğunu göstermektedir.

Panel veri modellerinde test edilmesi gereken önemli varsayımlarından bir tanesi de birimler arası korelasyondur. Birimler arası korelasyon, tahmin edilen modelin hata terimlerinin birimlere göre bağımsız olduğu anlamına gelmektedir. Yapılan analizde, serilere bir şok verilmesi halinde tüm birimlerin aynı derecede etkilenip etkilenmediği ve hata terimlerinin yatay kesitler boyunca eşzamanlı korelasyona sahip olup olmadığı önemlidir (Vergil ve Bahtiyar, 2017: 682). Bu çalışmada, birimler arası korelasyon sınaması Pesaran testi ile araştırılmıştır.

Tablo 9. Birimler Arası Korelasyon Testi

Pesaran $=4.533 \operatorname{Pr}=0.0000$

Tablo 9 incelendiğinde, test istatistiğinin \%5 anlamlılık düzeyinde olduğu, tesadüfi etkiler modeli için birimler arası korelasyon yoktur hipotezinin reddedildiği ve birimler arası korelasyonun mevcut olduğunu görülmektedir. Yapılan tüm testler neticesinde tesadüfi etkiler modeli için değişen varyans, otokorelasyon, ve birimler arası korelasyon problemlerinin varlığı belirlenmiştir.

Serilerin durağanlığını test etmek için hangi birim kök testinin uygulanabileceği birimler arası korelasyon testine göre belirlenmiştir. Birimler arası korelasyonun varlığının tespiti sonrası, serilerin durağanlığının sınanması için Im, Pesaran ve Shin (2003) birim kök testi uygulanmıştır. Serilerin durağanlığının test edildiği birim kök testi sonuçları tablo $10^{\prime}$ da gösterilmektedir.

Tablo 10. Im, Pesaran ve Shin Birim Kök Testi

\begin{tabular}{lcccc}
\hline \multicolumn{2}{l}{ DeğişkenlerTest istatistik değeri } & Olasılık değeri & $\begin{array}{c}\text { Test Istatistik değeri } \\
\text { I. fark }\end{array}$ & Olasılık değeri \\
\hline LnGDPPERCAP & -0.9895 & 0.1612 & -4.6514 & 0.0000 \\
RD & 0.3896 & 0.6516 & -5.4435 & 0.0000 \\
LnEXC & -0.2048 & 0.4189 & -5.2176 & 0.0000 \\
\hline
\end{tabular}


Tablo 10 incelendiğinde, ekonomik büyüme, Ar-Ge harcamaları ve reel efektif döviz kuru değişkenlerinin anlamlı istatistik değerlerine sahip olmadığı görülmektedir. Dolayısıyla bu değişkenlerin düzeyde durağan olmadığı, birim kökün varlığı belirlenmiştir. Durağan olmayan bu değişkenler için fark alınarak tekrar durağanlık sınaması yapıldığında ise birinci dereceden fark düzeyinde durağan oldukarı tespit edilmiştir.

$\mathrm{Bu}$ çalışmada kullanılacak regresyon yöntemi, literatürde değişen varyans ve otokorelasyon problemlerine karşı karşı dirençli bir tahmin yöntemi olan "Arellano, Froot ve Rogers Tahmincisi" olarak belirlenmiştir. Regresyon analizi sonuçları tablo 11'de gösterildiği gibidir.

Tablo 11. Arellano, Froot ve Rogers Tahmincisi Sonuçları

\begin{tabular}{lll}
\hline LnGDPPERCAP & Katsayılar & Robust Standart Hata \\
\hline RD & .3633749 & .1093467 \\
& $(0.001)^{*}$ & \\
LnEXC & .5699006 & .2649527 \\
& $(0.030)^{*}$ & \\
\hline
\end{tabular}

$\mathrm{R}^{2}: 0.4691$

Rho Katsayısı: .96133028

Wald Test İstatistiği: 11.05

Olasılık Değeri: $(0.0040)^{*}$

Gözlem Sayısı: 159

Açıklamalar: Parantez içerisindeki rakamlar, ilgili katsayılara ilişkin olasılık (p) değerlerini ifade etmektedir.

* işareti ilgili katsayının \%1 önem düzeyinde istatistiksel açıdan anlamlı olduğunu göstermektedir.

Modellerde, Rho katsayısı birim etkinin toplam içindeki payını ifade etmekte ve yüksek olması birim etkinin önemli olduğu anlamına gelmektedir. Wald test istatistiği ve olasılık değeri, tüm bağımsız değişkenlerin bağımlı değişken üzerindeki anlamlılığını, diğer bir ifadeyle modelin tümünün anlamlılığını göstermektedir.

Tablo 11 incelendiğinde, G8 ülkelerinde Ar-Ge harcamalarının ekonomik büyüme üzerinde pozitif ve anlamlı bir etkisi olduğu görülmektedir. Ar-Ge harcamalarındaki \%1'lik bir artış ekonomik büyüme üzerinde 0.363 birimlik, reel efektif döviz kurunda meydana gelen \%1'lik bir artış ise ekonomik büyüme üzerinde 0.569 birimlik bir artışa yol açmaktadır. Tahmin edilen modelin açıklama gücünü temsil eden R-kare değerinin ise \%46.9 olduğu tespit edilmiştir.

\section{Sonuç ve Değerlendirme}

Küreselleşme ve teknoloji kullanımının artması, dünya ülkelerin yenilik ve gelişmeleri yakından takip etmesini zorunlu kılmıştır. Ar-Ge faaliyetleri sonucu ortaya çıkan yenilikler, gelişmiş ekonomilerde ekonomik büyümenin en önemli unsurları arasında yer almaktadır. Teknolojik anlamda yenilikçi olan ülkeler, diğer ülkelere kıyasla rekabet üstünlüğü elde etmekte ve ekonomik olarak daha güçlü konuma gelmektedirler. Bu çalışmada, 1997-2017 dönemi yıllık verileri ile G8 ülkeleri için, Ar-Ge harcamalarının ekonomik büyüme üzerindeki etkisini, panel veri analizi yöntemi ile incelenmiştir. 
Ar-Ge faaliyetleri sonucu meydana gelen teknolojik yeniliklerin, ekonomik büyüme üzerindeki etkisi uzun yıllardır araştırılan bir konu olmuştur. Literatürde Ar-Ge ve ekonomik büyüme arasındaki ilişkinin yönünü ve boyutunu araştırmaya yönelik yapılan bir çok çalışma bulunmaktadır. Bu çalışmanın bulguları, Ar-Ge harcamalarının ekonomik büyüme üzerindeki etkisinin literatürle uyumlu olarak pozitif ve istatistiki olarak anlamlı olduğunu göstermektedir.

Ar-Ge faaliyetleri, bir ülkede yaşayan insanların yaşam standartlarını daha yüksek seviyeye çıkarmaya yönelik çalışmaları kapsadığı için bu faaliyetler için yapılan harcamalar büyük önem taşımaktadır. Ayrıca Ar-Ge faaliyetlerine yönelik yapılan harcamalar, ülkelerin ekonomik olarak büyümesi ve uluslararası alanda rekabet gücü elde edebilmesi için de en önemli unsurlardandır. Bu sebeple, Ar-Ge faaliyetlerinin gerek özel sektör gerekse kamu sektörü tarafından desteklenmesi gerekmektedir. Ülkeler, rekabet edebilirlik gücü kazanmak için Ar-Ge ve yenilik faaliyetlerine yönelik teşvik mekanizmaları geliştirmeli ve bu faaliyetlere daha fazla kaynak ayırmalıdır. Ayrıca Ar-Ge faaliyetlerine yönelik yeni hizmet alanlarının oluşturulması, yeni istihdam alanları da yaratarak ülke ekonomisini pozitif etkileyecektir.

\section{Kaynakça}

Altay, B., Tuğcu, C. T. ve Topcu, M. (2011). İşsizlik ve Enflasyon Oranları Arasındaki Nedensellik İlişkisi: G8 Ülkeleri Örneği. Afyon Kocatepe Üniversitesi İktisadi ve İdari Bilimler Fakültesi Dergisi, 13(2): 1-26.

Altin, O. ve Kaya, A. (2009). Türkiye'de Ar-Ge Harcamalari Ve Ekonomik Büyüme Arasindaki Nedensel İlişkinin Analizi. Ege Akademik Bakış, 9(1): 251-259.

Altıntaş, H. ve Mercan, M. (2015). Ar-Ge Harcamaları ve Ekonomik Büyüme İlişkisi: Oecd Ülkeleri Üzerine Yatay Kesit Bağımlılığı Altında Panel Eşbütünleşme Analizi. Ankara Üniversitesi SBF Dergisi, 70(2), 345-376.

Audretsch, D. B. (2018). Entrepreneurship, Economic Growth, and Geography. Oxford Review of Economic Policy, 34(4), 637-651.

Blanco, L. R., Gu, J. ve Prieger, J. E. (2016). The Impact of Research and Development on Economic Growth and Productivity in the US States. Southern Economic Journal, 82(3): 914934.

Del Monte, A. ve Papagni, E. (2003). R\&D and The Growth of Firms : Empirical Analysis of A Panel of Italian Firms. Research Policy, 32(6): 1003-1014.

Dünya Bankası. (2019). GDP Capita, https://data.worldbank.org/indicator/NY.GDP.PCAP.CD, erişim tarihi: 29.07.2019.

Dünya Bankasi. (2019). Population, Total, https://data.worldbank.org/indicator/SP.POP.TOTL, erişim tarihi: 29.07.2019.

Ertek, T. (2009). Temel Ekonomi. İstanbul: Beta Yayınları.

Fogarty, B. J. (2018). Quantitative social science data with R: an introduction. SAGE Publications Limited. 
Freimane, R. ve Balina, S. (2016). Research and Development Expenditures and Economic Growth in the EU: A Panel Data Analysis. Economics and Business, 29(1): 5-10.

Goel, R. K. ve Ram, R. (1994). Research And Development Expenditures And Economic Growth: A Crosscountry Study. Economic Development and Cultural Change, 42(2): 403-11.

Göçer, İ. (2013). Ar-Ge harcamalarının yüksek teknolojili ürün ihracatı, dış ticaret dengesi ve ekonomik büyüme üzerindeki etkileri. Maliye Dergisi, 165(2): 215-240.

Gülmez, A. ve Yardımcıŏlu, F. (2012). OECD Ülkelerinde Ar-Ge Harcamaları ve Ekonomik Büyüme İlişkisi: Panel Eşbütünleşme ve Panel Nedensellik Analizi (1990-2010). Maliye Dergisi, 163(1): 335-353.

Güriş, S. (2015). Stata ile Panel Veri Modelleri. İstanbul: Der Yayınları.

Hajnal, P. (2016). The G8 System And The G20: Evolution, Role and Documentation. New York: Routledge.

Jones, C. I. (2001). İktisadi Büyümeye Giriş. İstanbul: Literatür Yayınları.

Lichtenberg, Frank R. (1993). R\&D Investment and International Productivity Differences. NBER Working Paper Series, Vol.W4161.

OECD. (2019). Gross Domestic Spending on R\&D, https://data.oecd.org/rd/gross-domesticspending-on-r-d.htm, erişim tarihi: 28.07.2019.

Özkan, G. ve Yılmaz, H. (2017). Ar-Ge Harcamalarının Yüksek Teknoloji Ürün İhracatı ve Kişi Başı Gelir Üzerindeki Etkileri: 12 AB Ülkesi ve Türkiye İçin Uygulama (1996-2015). Bilgi Ekonomisi ve Yönetimi Dergisi, 12(1): 1-12.

Öztürk, M. B. E. (2016). Uluslararası Ekonomik Entegrasyonlar ve Kuruluşlar. Bursa: Ekin Yayınları.

Pece, A. M., Simona, O. E. O. ve Salisteanu, F. (2015). Innovation and Economic Growth: An Empirical Analysis for CEE Countries. Procedia Economics and Finance, 26: 461-467.

Pradhan, R. P., Arvin, M. B., Hall, J. H., ve Nair, M. (2016). Innovation, financial development and economic growth in Eurozone countries. Applied Economics Letters, 23(16), 1141-1144.

Saatçioğlu, C. ve Bildirici, Ü. (2017). İnovasyon Göstergeleri Bakımından Türkiye'nin OECD Ülkeleri Arasındaki Yeri: Ekonometrik Bir Uygulama. Isletme ve Iktisat Calismalari Dergisi, 5(4): 44-56.

Sağlam, Y., Egelï, H. A. ve Egeli, P. (2017). Gelişmiş ve Gelişmekte Olan Ülkelerde Ar\&Ge Harcamaları ve Ekonomik Büyüme Arasındaki İlişki: Panel Veri Analizi. Sosyoekonomi, 25(31): 149-165.

Samimi, A. J. ve Alerasoul, S. M. (2009). R\&D and Economic Growth: New Evidence From Some Developing Countries. Australian Journal of Basic and Applied Sciences, 3(4): 34643469.

Seyidoğlu, H. (2009). Uluslararası iktisat. İstanbul: Gizem Can Yayınları.

Shefer, D. ve Frenkel, A. (2005). R\&D, Firm Size And İnnovation: An Empirical Analysis. Technovation, 25(1):25-32. 
Ülkü, H. (2004). R\&D, Innovation, and Economic Growth: An Empirical Analysis, IMF Working Paper, No.04/185.

Ünal, T. ve Seçilmiş, N. (2013). Ar-Ge Göstergeleri Açısından Türkiye ve Gelişmiş Ülkelerle Kıyaslaması. İşletme ve İktisat Çalışmaları Dergisi, 1(1), 12-25.

Vergil, H. ve Bahtiyar, B. (2017). Ekonomik Büyüme Farklılıklarının Açıklanmasında Sosyal Sermayenin Etkisi: Güven Düzeyi Üzerinden Karşılaştırmalı Bir Analiz. Uluslararası Yönetim İktisat ve İşletme Dergisi, 13(5), 673-686.

Yıldırım, D. Ç. ve Kantarcı, T. (2014). Araştırma Geliştirme Harcamaları ve Ekonomik Büyüme İlişkisi Üzerine Bir Panel Veri Analizi. Anemon Muş Alparslan Üniversitesi Sosyal Bilimler Dergisi, 6(5): 661-670. 